Sains Malaysiana 49(10)(2020): 2465-2476

http://dx.doi.org/10.17576/jsm-2020-4910-12

\title{
Time-Kill Assay of N-(2-Bromoethyl)-7-Chloroquinilin-4-Amine (ACP 4A) with Fungistatic Activity against Aspergillus fumigatus
}

(Asai Masa Kematian Sebatian N-(2-Bromoetil)-7-Kloroquinilin-4-Amina (ACP 4A) dengan Aktiviti Fungistatiknya terhadap Aspergillus fumigatus)

\section{Dayang Fredalina Basri, Kuek Sze Yee, Jacinta Santhanam, Mohd Asyraf Shamsudin, Nur Hanis ZAKARIA, JALIFAH LATIP \& NURUL IZZATY HASSAN*}

\begin{abstract}
Six pyrano[2,3-c]pyrazole-3-carboxylate and quinoline derivatives $(A C P 1 A, A C P 1 B, A C P 1 C, A C P 1 D, A C P 2 A$ and $A C P 4 A$ ) synthesized and screened for antimicrobial activity against two selected Gram-positive bacteria (Staphylococcus aureus and Bacillus subtilis), three Gram-negative bacteria (Klebsiella pneumonia, Pseudomonas aeruginosa, and Escherichia coli), two yeast strains (Candida albicans and Candida glabrata) and two filamentous fungi (Aspergillus niger and Aspergillus fumigatus) using agar well diffusion method. Minimum inhibitory concentration (MIC) and minimum bactericidal/fungicidal concentration (MBC/MFC) of the compounds were determined using broth microdilution and streak plate method, respectively. Time-kill assay (TKA) analysis of N-(2-bromoethyl)-7-chloroquinilin-4-amine (ACP 4A) was subsequently conducted throughout the $24 \mathrm{~h}$ incubation period against A. fumigatus. Only ACP $4 A$ was chosen for the evaluation of TKA analysis because the broth dilution assay confirmed that it is the most potent compound with antifungal activity. E. coli was the only one found to be susceptible to the ACP $4 \mathrm{~A}$ compound at 20 and $30 \mathrm{mg}$ $m L^{-1}$ with an inhibition zone value of $15.00 \pm 0.00$ and $19.00 \pm 0.00 \mathrm{~mm}$, respectively. MIC values of ACP $4 A$ compound

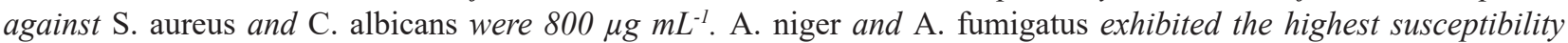

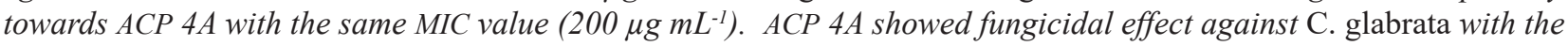

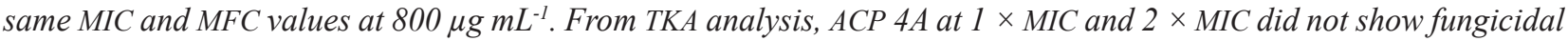
activity against $\mathrm{A}$. fumigatus. In conclusion, $A C P 4 A$ has the potential to be developed as a fungistatic (non-fungicidal) antifungal agent, which is an advantage compared to other known fungicidal compounds, particularly in patients with a healthy immune system.
\end{abstract}

Keywords: Antimicrobial; bacteria; fungi; pyrano[2,3-c] pyrazole-3-carboxylate; quinoline

ABSTRAK

Enam terbitan kumpulan pirano[2,3-c]pirazola-3-karboksil dan kuinolina (ACP 1A, ACP 1B, ACP 1C, ACP 1D, ACP $2 A$, dan ACP 4A) telah disaring untuk aktiviti antimikrob ke atas dua bakteria Gram positif (Staphylococcus aureus dan Bacillus subtilis), tiga bakteria Gram negatif(Klebsiella pneumoniae, Pseudomonas aeruginosa dan Escherichia coli), dua strain yis (Candida albicans dan Candida glabrata) dan dua spesies fungus berfilamen (Aspergillus niger dan Aspergillus fumigatus) menggunakan kaedah resapan telaga. Nilai kepekatan perencatan minimum (MIC) dan kepekatan bakterisid/fungisid minimum (MBC/MFC) sebatian ditentukan menggunakan kaedah mikropencairan kaldu dan teknik coretan plat. Asai masa kematian (TKA) sepanjang tempoh inkubasi selama 24 jam untuk sebatian $N$-(2-Bromoetil)-7-klorokuinilin-4-amina (ACP 4A) ditentukan ke atas A. fumigatus. Hanya E. coli sahaja didapati rentan terhadap sebatian $A C P 4 A$ pada 20 dan $30 \mathrm{mg} \mathrm{mL}^{-1}$ dengan nilai zon perencatan masing-masing, $15.00 \pm 0.00$ dan $19.00 \pm 0.00 \mathrm{~mm}$. Nilai MIC sebatian ACP 4A terhadap S. aureus dan C. albicans adalah $800 \mu \mathrm{g} \mathrm{mL} L^{-1}$. A. niger dan A. fumigatus menunjukkan kerentanan yang paling tinggi terhadap sebatian ACP 4A dengan nilai MIC yang sama (200 $\mu g \mathrm{~mL}^{-1}$ ). Sebatian ACP 4 A menunjukkan kesan fungisid ke atas $\mathrm{C}$. glabrata dengan nilai MIC dan MFC yang sama iaitu $800 \mu \mathrm{g} \mathrm{mL} L^{-1}$. Daripada analisis TKA, ACP 4A pada $1 \times$ MIC dan $2 \times$ MIC tidak menunjukkan aktiviti fungisid terhadap A. fumigatus. Kesimpulannya, sebatian $A C P 4 A$ berpotensi untuk dimajukan sebagai agen antikulat fungistatik yang merupakan kelebihan berbanding dengan agen fungisid yang lain, terutamanya pada pesakit dengan immunisasi yang baik.

Kata kunci: Antimikrob; bakteria; kuinolina; kulat; pirano[2,3-c]pirazola-3-karboksil 


\section{INTRODUCTION}

Infection of bacteria and yeast can occur through direct or indirect contact with the infected patients or due to opportunistic infection. Bacteria that are commonly isolated from the clinical setting are Staphylococcus sp., Streptococcus sp., Klebsiella sp., Pseudomonas sp., and Escherichia coli. Meanwhile, yeast (Candida sp.) and filamentous fungi (Aspergillus sp.) are often the cause for severe and life-threatening infections, especially in those with immunocompromised state of conditions. Examples of antibiotic drug classes often used in the clinical setting include glycopeptide, aminoglycoside, tetracycline, macrolide penicillin, cephalosporin, and fluoroquinolone. However, the increase of antibiotic synthesis has also caused problems such as toxicity side effects in consumers. Examples of antifungal agent groups are polyenes, pyrimidine, and azole. Amphotericin B is one of the drugs under the polyene group, but it can lead to nephrotoxicity (Joly et al. 1992). Therefore, the discovery of alternative drugs in treating bacterial and fungal infections is necessary.

Synthesis of pyrano[2,3-c]pyrazole-3-carboxylate derivatives was achieved under green catalysis-free via cyclization of four-component reactions comprising different carbonyl compound, malononitrile, and hydrazine derivatives (Mohammat et al. 2018). Quinoline is a heterocyclic aromatic organic compound that consists of a benzene ring fused to pyridine at two adjacent carbons. As a significant class of pharmaceutically active heterocyclic compounds, quinoline and its derivatives demonstrated different pharmacological activities such as anticancer (Kamath et al. 2016), anticonvulsive (Pawar et al. 2017), anti-inflammatory (Upadhyay et al. 2018), antimalarial and antiparasitic (Kaur et al. 2010) activities. The in vitro antimicrobial activity of four new series of quinoline derivatives against Escherichia coli, Staphylococcus aureus, Pseudomonas aeruginosa, and Klebsiella pneumonia and Mycobacterium tuberculosis were demonstrated (Eswaran et al. 2010). The quinoline and its derivatives inhibited the growth of $S$. pyogens, $S$. aureus (Gram-positive), and E. coli, P. aeruginosa (Gram-negative), and antifungal activity towards $A$. niger and $A$. clavatus from disc diffusion assay (Vaghasiya et al. 2014). Ambethkar et al. (2015) also showed that dihydropyranol[2,3-c]pyrazole derivatives were inhibitory by agar well diffusion method against Staphylococcus albus, Streptococcus pyogenes, Klebsiella pneumonia, Pseudomonas aeruginosa, and Candida albicans.

Quinoline structures have been identified in several synthetic, and natural antifungals due to certain structural features producing biological effects more than others. The heterocyclic quinoline system comprising carbon and nitrogen makes the privileged scaffold recognizable within various drug structures with the capability of achieving interesting pharmacological properties such as an antibiotic, antifungals, antibacterial and antineoplastic activities (Constantino \& Barlocco 2006). New trends in the design of quinolines with antifungal properties, their possible targets, and the structure-activity relationship proved that it is a valuable scaffold for the rising demand for new antifungals drugs (Musiol et al. 2010a).

A simple modification to 8-hydroxyquinoline provides an interesting fungicide since the fungistatic activity of this compound has been known for many decades. Halogenation on the quinoline ring of 8-hydroxyquinoline derivatives has been shown improvement on the fungitoxicity properties compared to the non-halogenated quinoline parent compound (Musiol et al. 2010b). Nevertheless, O-functionalized quinolines such as 5-,6and 8-(4-aminobutyloxy) quinolines have also been considered as a new class of antifungal agents besides their good potency as antimalarial due to the moderate cytotoxicity (Vandekerckhove et al. 2013).

The minimum concentration that inhibits 80 or $50 \%$ of fungal growth of two clinically important species, $C$. albicans and C. neoformans were tested on quinoline-based chalcones compound (Ramírez-Prada et al. 2017). It was apparent that $C$. neoformans were more sensitive than $C$. albicans with low $\mathrm{MIC}_{50}$ and $\mathrm{MIC}_{80}$ of $7.8 \mu \mathrm{g} \mathrm{mL}^{-1}$ since most of the clinically used antifungals are active at a MIC level $\leq 10 \mu \mathrm{g} \mathrm{mL}^{-1}$.

On the other hand, quinoline derivatives bearing pyrazole moiety showed fourfold potency of amphotericin $\mathrm{B}$ in inhibiting the growth of A. clavatus (MIC $0.49 \mu \mathrm{g}$ $\mathrm{mL}^{-1}$ ) and C. albicans (MIC $0.12 \mu \mathrm{g} \mathrm{mL}^{-1}$ ), respectively. The same compound also showed twofold potency against the same reference drugs in inhibiting the growth of A. fumigatus (MIC $0.98 \mu \mathrm{g} \mathrm{mL}^{-1}$ ), thus suggesting this attractive scaffold for the development of possible antifungal agents (El Shehry et al. 2018).

As such, quinoline derivatives can be regarded as a promising lead in synthesizing novel antimicrobial agents. Therefore, the antimicrobial activity of the six newly synthesized pyrano[2,3-c]pyrazole-3-carboxylate and quinoline compounds, as shown in Table 1, were assessed against selected bacteria and fungi in the hope of developing an alternative antimicrobial agent to treat the bacterial and fungal infection with minimal side effects.

\section{MATERIALS AND METHODS}

GENERAL PROCEDURE FOR THE SYNTHESIS OF PYRANO[2,3-C]PYRAZOLE -3-CARBOXYLATE (ACP 1AACP1D)

To a solution of diethylaxaloacetate sodium salt (5.5 $\mathrm{mmol}$ ) in $10 \mathrm{~mL}$ ethanol was added $35 \%$ hydrazine solution $(5.5 \mathrm{mmol})$ and $1 \mathrm{~mL}$ of acetic acid and refluxed for 15 min. Carbonyl compound ( $5 \mathrm{mmol})$ and malononitrile (5 
mmol) added to the reaction mixture, and heating continued for an additional $15 \mathrm{~min}$. The reaction was left to cool, and the resulting solid was filtered off and washed with water to furnish the pure product.

\section{SYNTHESIS OF ETHYL 6-AMINO-5-CYANO-4-PHENYL-1,4- DIHYDROPYRANO[2,3-C]PYRAZOLE-3-CARBOXYLATE} (ACP1A)

The procedure, as mentioned, was followed. ACP 1A was isolated as a colorless solid (55\%). m.p 224-225 ${ }^{\circ} \mathrm{C}$ (Reported: $\left.226-227^{\circ} \mathrm{C}\right) ; \delta_{\mathrm{H}}(400 \mathrm{MHz}, \mathrm{DMSO}) 7.24(\mathrm{t}, J=$ $7.3 \mathrm{~Hz}, 2 \mathrm{H}), 7.15$ (t, $J=7.3 \mathrm{~Hz}, 1 \mathrm{H}), 7.05$ (t, $J=4.3 \mathrm{~Hz}$, 2H), 6.99 (s, 2H), 4.70 (s, 1H), 4.04 (q, $J=7.3 \mathrm{~Hz}, 2 \mathrm{H})$, $1.00(\mathrm{t}, J=7.1 \mathrm{~Hz}, 3 \mathrm{H}) ;{ }^{13} \mathrm{C}(100 \mathrm{MHz}, \mathrm{DMSO}): 160.5$ $\left(\mathrm{CNH}_{2}\right), 158.7(\mathrm{C}=\mathrm{O}), 156.1(\mathrm{CNH}), 142.4$ (quat. $\left.\mathrm{Ar} \mathrm{C}\right)$, 129.6 (C=N), 128.8 (Ar C), $127.9($ Ar C), 127.1 (Ar C), $120.8(\mathrm{CN}), 104.1$ (quat. C), $61.3\left(\mathrm{CH}_{2}\right), 58.4$ (quat. C), $37.5(\mathrm{CH}), 14.3\left(\mathrm{CH}_{3}\right)$. Anal. calc. for $\mathrm{C}_{16} \mathrm{H}_{14} \mathrm{~N}_{4} \mathrm{O}_{3} \mathrm{C}$ 61.93, H 4.55, N 18.06. Found: C 62.04, H 4.52, N 20.83.

SYNTHESIS OF ETHYL 6-AMINO-5-CYANO-4-(4ETHYLPHENYL)-1,4-DIHYDROPYRANO[2,3-C]PYRAZOLE-3CARBOXYLATE (ACP1B)

The procedure mentioned before was repeated, and ACP 1B was isolated as yellowish solid (50\%); m.p 212-213 ${ }^{\circ} \mathrm{C}$ (Reported: $\left.212-213{ }^{\circ} \mathrm{C}\right) ; \delta_{\mathrm{H}}(400 \mathrm{MHz}, \mathrm{DMSO}) 7.07$ (d, $J=8.2 \mathrm{~Hz}, 2 \mathrm{H}), 6.96$ (s, 2H), 6.95 (d, $J=7.6 \mathrm{~Hz}, 2 \mathrm{H})$, 4.67 (s, 1H), 4.07 (q, $J=7.0 \mathrm{~Hz}, 2 \mathrm{H}), 2.52$ (q, $J=7.5 \mathrm{~Hz}$, $2 \mathrm{H}), 1.10(\mathrm{t}, J=7.5 \mathrm{~Hz}, 3 \mathrm{H}), 1.01(\mathrm{t}, J=7.1 \mathrm{~Hz}, 3 \mathrm{H}) ;{ }^{13} \mathrm{C}$ (100 MHz, DMSO): $160.5\left(\mathrm{CNH}_{2}\right), 158.7(\mathrm{C}=\mathrm{O}), 156.1$ (CNH), 145.5 (quat. Ar C), $129.6(\mathrm{C}=\mathrm{N}), 128.8$ (Ar C), 127.9 (Ar C), 127.1 (Ar C), $120.8(\mathrm{CN}), 104.1$ (quat. C), $61.3\left(\mathrm{CH}_{2}\right), 58.4$ (quat. C), $37.5(\mathrm{CH}), 14.3\left(\mathrm{CH}_{3}\right)$; Anal. calc. for $\mathrm{C}_{18} \mathrm{H}_{18} \mathrm{~N}_{4} \mathrm{O}_{3}, \mathrm{C} 63.89, \mathrm{H} 5.36, \mathrm{~N}$ 16.56. Found: $\mathrm{C}$ $64.46, \mathrm{H} 5.41, \mathrm{~N} 18.71$.

SYNTHESIS OF ETHYL 6-AMINO-5-CYANO-4-(FURAN-2-YL)1,4-DIHYDROPYRANO[2,3-C]PYRAZOLE-3-CARBOXYLATE (ACP1C)

The procedure, as mentioned before, was followed. ACP $1 \mathrm{C}$ was isolated as yellowish solid (61\%); m.p 217-218 ${ }^{\circ} \mathrm{C}$ (Reported: $\left.216-218{ }^{\circ} \mathrm{C}\right) ; \delta_{\mathrm{H}}(400 \mathrm{MHz}, \mathrm{DMSO}): 7.44$ $(\mathrm{d}, J=2.7 \mathrm{~Hz}, 1 \mathrm{H}), 7.08(\mathrm{~s}, 2 \mathrm{H}), 6.31(\mathrm{dd}, J=3.2 \mathrm{~Hz}, 1.8$ $H z, 1 \mathrm{H}), 6.07$ (d, $J=2.7 \mathrm{~Hz}, 1 \mathrm{H}), 4.88(\mathrm{~s}, 1 \mathrm{H}), 4.14$ (q, $J=6.2 \mathrm{~Hz}, 2 \mathrm{H}), 1.13(\mathrm{t}, J=7.1 \mathrm{~Hz}, 3 \mathrm{H}) ;{ }^{13} \mathrm{C}(100 \mathrm{MHz}$, DMSO): $161.3\left(\mathrm{CNH}_{2}\right), 158.8(\mathrm{C}=\mathrm{O}), 156.2(\mathrm{CNH}), 156.0$ (quat. C.), 142.4 (CH), 129.6 (quat C.) 120.7 (CN), 110.9 $(\mathrm{CH}), 106.0(\mathrm{CH}), 101.5$ (quat. $\mathrm{C}), 61.5\left(\mathrm{CH}_{2}\right), 55.3$ (quat. C), $31.2(\mathrm{CH}), 14.4\left(\mathrm{CH}_{3}\right)$; Anal. calc. for $\mathrm{C}_{14} \mathrm{H}_{12} \mathrm{~N}_{4} \mathrm{O}_{4}, \mathrm{C}$ 56.00, H 4.03, N 18.66. Found: C 56.29, H 4.04, N 21.32.

\section{SYNTHESIS OF ETHYL 6-AMINO-5-CYANO-4-ISOPROPYL- 1,4-DIHYDROPYRANO[2,3-C]PYRAZOLE-3-CARBOXYLATE (ACP1D)}

The procedure mentioned before was followed. ACP 1D was isolated as a colorless solid (57\%); m.p: $189-190{ }^{\circ} \mathrm{C}$
(Reported: $\left.200-201{ }^{\circ} \mathrm{C}\right) ; \delta_{\mathrm{H}}(400 \mathrm{MHz}, \mathrm{DMSO}): 6.97$ (s, 2H), 4.40-4.09 (dt, $J=6.8,3.6 \mathrm{~Hz}, 2 \mathrm{H}), 3.58(\mathrm{~d}, J=2.7 \mathrm{~Hz}$, $1 \mathrm{H}), 2.12-1.85(\mathrm{~m}, 1 \mathrm{H}), 1.28(\mathrm{t}, J=7.1 \mathrm{~Hz}, 3 \mathrm{H}), 0.94(\mathrm{~d}$, $J=6.9 \mathrm{~Hz}, 3 \mathrm{H}), 0.57(\mathrm{~d}, J=6.9 \mathrm{~Hz}, 3 \mathrm{H}) ; \mathrm{RMN}{ }^{13} \mathrm{C}(100$ MHz, DMSO): $163.5\left(\mathrm{CNH}_{2}\right), 159.2(\mathrm{C}=\mathrm{O}), 157.0(\mathrm{CNH})$, 128.7 (quat. C), $122.3(\mathrm{CN}), 105.3$ (quat. C), $61.5\left(\mathrm{CH}_{2}\right)$, 51.8 (quat. C), 37.6 (CH), 35.7 (CH), $20.7\left(\mathrm{CH}_{3}\right), 17.2\left(\mathrm{CH}_{3}\right)$, $14.5\left(\mathrm{CH}_{3}\right)$; Anal. calc. for $\mathrm{C}_{13} \mathrm{H}_{16} \mathrm{~N}_{4} \mathrm{O}_{3}, \mathrm{C} 56.51, \mathrm{H} 5.84, \mathrm{~N}$ 20.28. Found: C 56.18, H 5.85, N 21.93.

\section{SYNTHESIS OF COMPOUND 2-((7-CHLOROQUINOLIN-4-YL) AMINO)ETHAN-1-OL (ACP2A)}

A mixture solution of 4,7-dichloroquinoline $(0.99 \mathrm{~g}, 5$ $\mathrm{mmol})$ and 2-aminoethanol (1.5 mL, $25 \mathrm{mmol})$ was heated at $120-130{ }^{\circ} \mathrm{C}$ for $3 \mathrm{~h}$ under nitrogen atmosphere. Upon completion, reaction mixture was transferred into ice cold water and stirred at $0{ }^{\circ} \mathrm{C}$ for an hour. The resulting precipitate was filtered, washed repeatedly with cold water three times and dried in a vacuum oven at $70{ }^{\circ} \mathrm{C}$ to yield a colorless solid with $93 \%$ yield. M.p $210-211^{\circ} \mathrm{C}$; $\delta_{\mathrm{H}}(400$ MHz, DMSO): 8.34 (d, $J=5.0 \mathrm{~Hz}, 1 \mathrm{H}), 8.21(\mathrm{~d}, J=8.7$ $H z, 1 \mathrm{H}), 7.74(\mathrm{~d}, J=2.3 \mathrm{~Hz}, 1 \mathrm{H}), 7.40(\mathrm{dd}, J=9.1,2.3$ $\mathrm{Hz}, 1 \mathrm{H}), 7.24(\mathrm{t}, J=5.5 \mathrm{~Hz}, 1 \mathrm{H}), 6.46(\mathrm{~d}, J=5.5 \mathrm{~Hz}, 1 \mathrm{H})$, $4.81(\mathrm{t}, J=5.5 \mathrm{~Hz}, 1 \mathrm{H}), 3.62(\mathrm{q}, J=5.8 \mathrm{~Hz}, 2 \mathrm{H}), 3.30(\mathrm{q}$, $J=5.8 \mathrm{~Hz}, 2 \mathrm{H}) ;{ }^{13} \mathrm{C}(100 \mathrm{MHz}, \mathrm{DMSO}) \delta 152.418$ (Ar C), 150.8 (quat. C), 149.6 (quat. C), 133.9 (quat. C), 128.0 (Ar C), 124.6 (Ar C), 124.5 (Ar C), 118.0 (quat. C), 99.2 (Ar C), $59.3\left(\mathrm{CH}_{2} \mathrm{Br}\right), 45.6\left(\mathrm{CH}_{2} \mathrm{~N}\right)$.

\section{SYNTHESIS OF N-(2-BROMOETHYL)-7-CHLOROQUINOLIN-4- AMINE (ACP4A)}

Compound ACP2A dissolved in aq. $\mathrm{HBr}(33 \%)$ solution at $0{ }^{\circ} \mathrm{C}$ and conc. $\mathrm{H}_{2} \mathrm{SO}_{4}$ added dropwise, maintaining the temperature at room temperature for $15 \mathrm{~min}$. The reaction mixture heated at $160^{\circ} \mathrm{C}$ for $3 \mathrm{~h}$. Subsequently, the reaction mixture transferred into ice-cold water, and ammonium hydroxide was added dropwise until $\mathrm{pH}$ 9. The resulting precipitate was filtered and added into a solution of toluene containing charcoal. The mixture was kept in the fridge at $4{ }^{\circ} \mathrm{C}$ to obtain a colorless solid (40\%); m.p 140$141{ }^{\circ} \mathrm{C} ; \delta_{\mathrm{H}}(400 \mathrm{MHz}, \mathrm{DMSO}): 8.36(\mathrm{~d}, J=5.5 \mathrm{~Hz}, 1 \mathrm{H})$, $8.06(\mathrm{~d}, J=9.1 \mathrm{~Hz}, 1 \mathrm{H}), 7.77(\mathrm{~d}, J=2.3 \mathrm{~Hz}, 1 \mathrm{H}), 7.40$ $(\mathrm{dd}, J=8.7,2.3 \mathrm{~Hz}, 1 \mathrm{H}), 6.56(\mathrm{~d}, J=5.5 \mathrm{~Hz}, 1 \mathrm{H}), 3.79(\mathrm{t}$, $J=6.6 \mathrm{~Hz}, 2 \mathrm{H}), 3.64(\mathrm{t}, J=6.4 \mathrm{~Hz}, 2 \mathrm{H}) ;{ }^{13} \mathrm{C}(100 \mathrm{MHz}$, $\mathrm{CD}_{3} \mathrm{OH}$ ): $\delta 151.1$ (Ar C), 150.9 (quat. C), 148.3 (quat. C), 135.2 (quat. C), $126.3(\mathrm{ArC}), 125.0(\mathrm{Ar} \mathrm{C}), 122.9(\mathrm{Ar} \mathrm{C})$, 117.4 (quat. C), 98.4 ( $\mathrm{Ar} \mathrm{C}), 44.2\left(\mathrm{CH}_{2} \mathrm{Br}\right), 29.0\left(\mathrm{CH}_{2} \mathrm{~N}\right)$.

\section{PREPARATION OF STOCK SOLUTION OF HETEROCYCLIC ORGANIC COMPOUNDS}

Pyrano[2,3-c]pyrazole-3-carboxylate and quinoline derivatives (ACP 1A, ACP 1B, ACP 1C, ACP 1D, ACP $2 \mathrm{~A}$ and $\mathrm{ACP} 4 \mathrm{~A})$ synthesized and characterized by the Department of Chemical Sciences, Faculty of Science and Technology. The molecular structure of these heterocyclic organic compounds was shown in Table 
1. Pyrano[2,3-c]pyrazole-3-carboxylate and quinoline compound at $40,000 \mu \mathrm{g} \mathrm{mL} \mathrm{m}^{-1}$ solution was prepared by solubilizing $0.4 \mathrm{~g}$ of these heterocyclic organic compounds powder into $10 \mathrm{~mL}$ DMSO. The stock solution mixed using vortex for $5 \mathrm{~min}$. The stock solution stored at $-20{ }^{\circ} \mathrm{C}$ until further use.

TABLE 1. Six heterocyclic organic compounds containing pyrano[2,3-c]pyrazole-3-carboxylate and quinoline moieties

\begin{tabular}{|c|c|c|c|}
\hline Entry & Name & Elements & Molecular structure \\
\hline ACP1A & $\begin{array}{l}\text { Ethyl 6-amino-5-cyano-4-phenyl- } \\
\text { 1,4-dihydropyrano[2,3-c]pyrazole-3- } \\
\text { carboxylate }\end{array}$ & $\mathrm{C}_{16} \mathrm{H}_{14} \mathrm{~N}_{4} \mathrm{O}_{3}$ & \\
\hline ACP1B & $\begin{array}{l}\text { Ethyl 6-amino-5-cyano- } \\
\text { 4-(4-ethylphenyl)-1,4- } \\
\text { dihydropyrano[2,3-c]pyrazole-3- } \\
\text { carboxylate }\end{array}$ & $\mathrm{C}_{18} \mathrm{H}_{18} \mathrm{~N}_{4} \mathrm{O}_{3}$ & \\
\hline $\mathrm{ACP} 1 \mathrm{C}$ & $\begin{array}{l}\text { Ethyl 6-amino-5-cyano-4-(furan- } \\
\text { 2-yl)-1,4-dihydropyrano[2,3-c] } \\
\text { pyrazole-3-carboxylate }\end{array}$ & $\mathrm{C}_{14} \mathrm{H}_{12} \mathrm{~N}_{4} \mathrm{O}_{4}$ & \\
\hline ACP1D & $\begin{array}{l}\text { Ethyl 6-amino-5-cyano-4-isopropyl- } \\
\text { 1,4-dihydropyrano[2,3-c]pyrazole-3- } \\
\text { carboxylate }\end{array}$ & $\mathrm{C}_{13} \mathrm{H}_{16} \mathrm{~N}_{4} \mathrm{O}_{3}$ & \\
\hline $\mathrm{ACP} 2 \mathrm{~A}$ & $\begin{array}{l}\text { 2-((7-chloroquinolin-4-yl)amino) } \\
\text { ethanol }\end{array}$ & $\mathrm{C}_{11} \mathrm{H}_{11} \mathrm{ClN}_{2} \mathrm{O}$ & \\
\hline ACP4A & $\begin{array}{l}\text { N-(2-bromoethyl)-7-chloroquinolin- } \\
\text { 4-amine }\end{array}$ & $\mathrm{C}_{11} \mathrm{H}_{10} \mathrm{BrClN}_{2}$ & \\
\hline
\end{tabular}

PREPARATION OF TEST MICROORGANISMS

Two Gram-positive bacteria (Staphylococcus aureus ATCC 25923 and Bacillus subtilis), three Gram-negative bacteria (Escherichia coli ATCC 25922, Klebsiella pneumonia, and
Pseudomonas aeruginosa ATCC 27853), two yeast strains (Candida albicans ATCC 900028 and Candida glabrata ATCC 64677) and two filamentous fungi (Aspergillus niger ATCC 6275 and Aspergillus fumigatus ATCC 
204305) were obtained from the Laboratory Collection Centre, Faculty of Health Sciences, Universiti Kebangsaan Malaysia, Kuala Lumpur (UKM KL). Bacteria and fungi were cultured on nutrient agar (NA) and potato dextrose agar (PDA), respectively, at Infectious Disease Laboratory, Faculty of Health Sciences, UKM KL. Bacteria and yeast incubated in $37^{\circ} \mathrm{C}$ overnight, while filamentous fungi incubated at a lower temperature of $30^{\circ} \mathrm{C}$ for 3 to 4 days. The seeding of filamentous fungi was prepared by adding $2 \mathrm{~mL}$ sterile $0.85 \% \mathrm{NaCl}$ and scraped off using a pipette tip followed by filtration through a double layer sterile gauze to remove large hyphae fragments for culture done by plug inoculation. The standardized inoculum size of all microorganisms were achieved by adjusting the optical density of bacteria and yeast suspension, respectively, at turbidity corresponding to an absorbance (A) reading at 0.08 at $625 \mathrm{~nm}$ and 0.11 to 0.14 at $530 \mathrm{~nm}$ which is equivalent to an estimated concentration of $10^{8} \mathrm{CFU} \mathrm{mL}^{-1}$ for bacteria and $10^{6} \mathrm{CFU} \mathrm{mL} \mathrm{m}^{-1}$ for yeast, respectively. As for filamentous fungi, the inoculum size was standardized to absorbance (A) reading within the range of 0.09 to 0.11 at $530 \mathrm{~nm}$ which corresponded to a range of $1.0 \times 10^{6}-5.0$ $\times 10^{6}$ spores $\mathrm{mL}^{-1}$.

\section{DETERMINATION OF ANTIMICROBIAL ACTIVITY USING AGAR WELL DIFFUSION ASSAY}

Six heterocyclic organic compounds were used for antibacterial and antifungal screening tests using the agar well diffusion method. Mueller-Hinton agar (MHA) uniformly seeded with test bacteria by spreading the inoculum on the surface of the agar plate with a sterile swab. On the other hand, PDA was applied as the seed medium for yeast and filamentous fungi. The agar wells ( $8 \mathrm{~mm}$ diameter) were punched and placed with the test compounds $(50 \mu \mathrm{L})$ at concentration 10,20 , and $30 \mathrm{mg}$ $\mathrm{mL}^{-1}$. For positive control, gentamicin $\left(10 \mu \mathrm{g} \mathrm{mL}^{-1}\right)$ was used for bacteria, whereas amphotericin B $\left(20 \mu \mathrm{g} \mathrm{mL}^{-1}\right)$ was applied for yeast and filamentous fungi. For negative control, 5\% DMSO was used for bacteria, whereas distilled water was used for yeast and filamentous fungi. The bacteria and yeast plates were incubated at $37{ }^{\circ} \mathrm{C}$ for 24 $\mathrm{h}$, whereas filamentous fungi plates were incubated at 30 ${ }^{\circ} \mathrm{C}$ for $36 \mathrm{~h}$. The test was done in duplicates to ensure the reliability of the compound assayed. The antimicrobial activity was performed by measuring the diameter of the zone of inhibition in $\mathrm{mm}$.

\section{DETERMINATION OF MINIMUM INHIBITORY CONCENTRATION (MIC) AND MINIMUM BACTERICIDAL/ FUNGICIDAL CONCENTRATION (MBC/MFC) ASSAY}

The MIC value of each compound can be identified by using a two-fold serial microdilution method in 96 well microtiter plates. Initially, $100 \mu \mathrm{L}$ of test compound at concentration $3200 \mu \mathrm{g} \mathrm{mL}^{-1}$ was added to $100 \mu \mathrm{L}$ sterile broth media. Subsequently, $100 \mu \mathrm{L}$ of diluted microorganism suspension with the final inoculum of

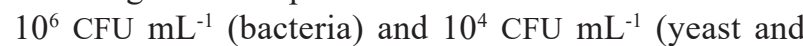
filamentous fungi) were combined into the 96 well plates. The microdilution fixed at a final compound concentration ranging from 25 to $800 \mu \mathrm{g} \mathrm{mL}^{-1}$. Each compound tested in triplicates. The compound in the broth was used as a negative control to ensure the sterility of medium.

Meanwhile, the microorganism suspensions served as a positive control to make sure the growth of the microorganism in the broth. The lowest concentration to inhibit the growth of microorganisms determined as MIC value. The MBC value was analyzed by sub-culturing the well with the lowest concentration displayed no-growth of microorganisms on a sterile agar plate.

\section{DETERMINATION OF RATE-KILLING ACTIVITY USING TIME- KILL ANALYSIS (TKA) ASSAY}

The time-kill curves of the compound evaluated using the broth microdilution assay. Initially, $10 \mathrm{~mL}$ suspension of fungus inoculum prepared using RPMI-1640 broth. The volume of fungus inoculum removed is the same as the volume of the compound added into the suspension to get $1 \times$ MIC and $2 \times$ MIC concentration of the compound. The growth control tube comprised only microorganisms and RPMI-1640 broth. The tubes were later incubated at $30^{\circ} \mathrm{C}$, and viable count performed at $0,2,4,6,8$, and $24 \mathrm{~h}$. At each hour, $0.1 \mathrm{~mL}$ of the sample removed from the tube was diluted ten-fold with $0.9 \mathrm{~mL}$ of $0.9 \%$ normal saline and spread on PDA plates using an L-shaped rod and incubated for $18 \mathrm{~h}$ at $30{ }^{\circ} \mathrm{C}$. The colony count of fungus for each plate was determined to obtain time-mortality curves by plotting the $\log _{10} \mathrm{CFU} \mathrm{mL} \mathrm{L}^{-1}$ on the $\mathrm{y}$-axis and time on the $\mathrm{x}$-axis. The fungicidal effect depicted if there was a decrease of $\geq 3 \log _{10} \mathrm{CFU} \mathrm{mL} \mathrm{mL}^{-1}$ in colony counts within $24 \mathrm{~h}$ while the fungistatic effect described if there was $\leq$ $3 \log _{10}$ CFU mL $\mathrm{mL}^{-1}$ reduction in colony counts within $24 \mathrm{~h}$.

\section{RESULTS}

\section{DETERMINATION OF INHIBITION ZONE}

The diameter of the inhibition zone of the compounds against five bacterial strains and four fungal species were shown in Tables 2 and 3, respectively. Based on the results obtained, only the ACP 4A showed the antimicrobial activity with the formation of an inhibition zone. Compared to Gentamicin $\left(10 \mu \mathrm{g} \mathrm{mL}^{-1}\right)$ which produced inhibition zone of $17.0 \pm 0.00 \mathrm{~mm}$ against $E$. coli, ACP 4 A was only capable of inhibiting the growth of E. coli at 20 and $30 \mathrm{mg} \mathrm{mL}^{-1}$, with an inhibition zone of $15.0 \pm 0.00$ and $19.0 \pm 0.00 \mathrm{~mm}$, respectively. In other words, among all the tested bacteria and fungi, only Escherichia coli was susceptible to ACP 4A. All the tested compounds were not able to inhibit the growth of $S$. aureus, B. subtilis, $K$. pneumoniae, $P$. aeruginosa, C. albicans, C. glabrata, $A$. niger, and A. fumigatus. 
TABLE 2. Mean diameter of inhibition zones of six heterocyclic organic compounds against five tested bacteria

\begin{tabular}{|c|c|c|c|c|c|c|}
\hline \multirow{3}{*}{ Tested bacteria } & \multirow{3}{*}{$\begin{array}{l}\text { Heterocyclic } \\
\text { compounds }\end{array}$} & \multirow{2}{*}{\multicolumn{3}{|c|}{$\begin{array}{l}\text { The diameter of inhibition zones } \\
(\text { mean } \pm \mathrm{SD})\end{array}$}} & \multirow[b]{3}{*}{$\begin{array}{c}\text { Positive } \\
\text { control }(\mathrm{mm})\end{array}$} & \multirow[b]{3}{*}{$\begin{array}{c}\text { Negative } \\
\text { control (mm) }\end{array}$} \\
\hline & & & & & & \\
\hline & & 10 & 20 & 30 & & \\
\hline \multirow{6}{*}{$\begin{array}{l}\text { Staphylococcus } \\
\text { aureus }\end{array}$} & ACP $1 \mathrm{~A}$ & - & - & - & $16.0 \pm 0.00$ & - \\
\hline & ACP 1B & - & - & - & $16.0 \pm 0.00$ & - \\
\hline & ACP 1C & - & - & - & $16.0 \pm 0.00$ & - \\
\hline & ACP 1D & - & - & - & $16.0 \pm 0.00$ & - \\
\hline & $\mathrm{ACP} 2 \mathrm{~A}$ & - & - & - & $16.0 \pm 0.00$ & - \\
\hline & $\mathrm{ACP} 4 \mathrm{~A}$ & - & - & - & $16.0 \pm 0.00$ & - \\
\hline \multirow{6}{*}{ Bacillus subtilis } & ACP 1A & - & - & - & $20.67 \pm 0.52$ & - \\
\hline & ACP 1B & - & - & - & $20.67 \pm 0.52$ & - \\
\hline & $\mathrm{ACP} 1 \mathrm{C}$ & - & - & - & $20.67 \pm 0.52$ & - \\
\hline & ACP 1D & - & - & - & $20.67 \pm 0.52$ & - \\
\hline & $\mathrm{ACP} 2 \mathrm{~A}$ & - & - & - & $20.67 \pm 0.52$ & - \\
\hline & $\mathrm{ACP} 4 \mathrm{~A}$ & - & - & - & $20.67 \pm 0.52$ & - \\
\hline \multirow{6}{*}{ Escherichia coli } & ACP $1 \mathrm{~A}$ & - & - & - & $17.0 \pm 0.00$ & - \\
\hline & ACP $1 \mathrm{~B}$ & - & - & - & $17.0 \pm 0.00$ & - \\
\hline & $\mathrm{ACP} 1 \mathrm{C}$ & - & - & - & $17.0 \pm 0.00$ & - \\
\hline & ACP 1D & - & - & - & $17.0 \pm 0.00$ & - \\
\hline & $\mathrm{ACP} 2 \mathrm{~A}$ & - & - & - & $17.0 \pm 0.00$ & - \\
\hline & $\mathrm{ACP} 4 \mathrm{~A}$ & - & $15.0 \pm 0.00$ & $19.0 \pm 0.00$ & $17.0 \pm 0.00$ & - \\
\hline \multirow{6}{*}{ Klebsiella pnemoniae } & ACP $1 \mathrm{~A}$ & - & - & - & $17.0 \pm 0.00$ & - \\
\hline & ACP 1B & - & - & - & $17.0 \pm 0.00$ & - \\
\hline & ACP 1C & - & - & - & $17.0 \pm 0.00$ & - \\
\hline & ACP 1D & - & - & - & $17.0 \pm 0.00$ & - \\
\hline & $\mathrm{ACP} 2 \mathrm{~A}$ & - & - & - & $17.0 \pm 0.00$ & - \\
\hline & $\mathrm{ACP} 4 \mathrm{~A}$ & - & - & - & $17.0 \pm 0.00$ & - \\
\hline \multirow{6}{*}{$\begin{array}{l}\text { Pseudomonas } \\
\text { aeruginosa }\end{array}$} & ACP $1 \mathrm{~A}$ & - & - & - & $15.0 \pm 0.00$ & - \\
\hline & ACP 1B & - & - & - & $15.0 \pm 0.00$ & - \\
\hline & ACP $1 \mathrm{C}$ & - & - & - & $15.0 \pm 0.00$ & - \\
\hline & ACP 1D & - & - & - & $15.0 \pm 0.00$ & - \\
\hline & $\mathrm{ACP} 2 \mathrm{~A}$ & - & - & - & $15.0 \pm 0.00$ & - \\
\hline & $\mathrm{ACP} 4 \mathrm{~A}$ & - & - & - & $15.0 \pm 0.00$ & - \\
\hline \multicolumn{7}{|l|}{ Note: } \\
\hline $\begin{array}{l}\text { Positive control } \\
\text { Negative control }\end{array}$ & $\begin{array}{l}\text { : No inhibition } \\
: \text { Gentamicin } 10 \\
.5 \% \text { DMSO }\end{array}$ & & & & & \\
\hline
\end{tabular}


TABLE 3. Mean diameter of inhibition zones of six heterocyclic organic compounds against four tested fungi

\begin{tabular}{|c|c|c|c|c|c|c|}
\hline \multirow{3}{*}{ Tested fungi } & \multirow{3}{*}{$\begin{array}{l}\text { Heterocyclic } \\
\text { compounds }\end{array}$} & \multirow{2}{*}{\multicolumn{3}{|c|}{$\begin{array}{l}\text { The diameter of inhibition zones } \\
(\text { mean } \pm \mathrm{SD})\end{array}$}} & \multirow[b]{3}{*}{$\begin{array}{c}\text { Positive } \\
\text { control (mm) }\end{array}$} & \multirow[b]{3}{*}{$\begin{array}{l}\text { Negative control } \\
(\mathrm{mm})\end{array}$} \\
\hline & & & & & & \\
\hline & & 10 & 20 & 30 & & \\
\hline \multirow{6}{*}{ Candida albicans } & ACP $1 \mathrm{~A}$ & - & - & - & $29.0 \pm 0.00$ & - \\
\hline & ACP 1B & - & - & - & $29.0 \pm 0.00$ & - \\
\hline & ACP 1C & - & - & - & $29.0 \pm 0.00$ & - \\
\hline & ACP 1D & - & - & - & $29.0 \pm 0.00$ & - \\
\hline & $\mathrm{ACP} 2 \mathrm{~A}$ & - & - & - & $29.0 \pm 0.00$ & - \\
\hline & $\mathrm{ACP} 4 \mathrm{~A}$ & - & - & - & $29.0 \pm 0.00$ & - \\
\hline \multirow{6}{*}{ Candida glabrata } & ACP 1A & - & - & - & $34.0 \pm 0.00$ & - \\
\hline & ACP 1B & - & - & - & $34.0 \pm 0.00$ & - \\
\hline & $\mathrm{ACP} 1 \mathrm{C}$ & - & - & - & $34.0 \pm 0.00$ & - \\
\hline & ACP 1D & - & - & - & $34.0 \pm 0.00$ & - \\
\hline & $\mathrm{ACP} 2 \mathrm{~A}$ & - & - & - & $34.0 \pm 0.00$ & - \\
\hline & $\mathrm{ACP} 4 \mathrm{~A}$ & - & - & - & $34.0 \pm 0.00$ & - \\
\hline \multirow{6}{*}{ Aspergillus niger } & ACP 1A & - & - & - & $23.7 \pm 1.51$ & - \\
\hline & ACP 1B & - & - & - & $23.7 \pm 1.51$ & - \\
\hline & $\mathrm{ACP} 1 \mathrm{C}$ & - & - & - & $23.7 \pm 1.51$ & - \\
\hline & ACP 1D & - & - & - & $23.7 \pm 1.51$ & - \\
\hline & $\mathrm{ACP} 2 \mathrm{~A}$ & - & - & - & $23.7 \pm 1.51$ & - \\
\hline & $\mathrm{ACP} 4 \mathrm{~A}$ & - & - & - & $23.7 \pm 1.51$ & - \\
\hline \multirow{6}{*}{$\begin{array}{l}\text { Aspergillus } \\
\text { fumigatus }\end{array}$} & ACP $1 \mathrm{~A}$ & - & - & - & $18.0 \pm 0.00$ & - \\
\hline & $\mathrm{ACP} 1 \mathrm{~B}$ & - & - & - & $18.0 \pm 0.00$ & - \\
\hline & ACP $1 C$ & - & - & - & $18.0 \pm 0.00$ & - \\
\hline & ACP 1D & - & - & - & $18.0 \pm 0.00$ & - \\
\hline & $\mathrm{ACP} 2 \mathrm{~A}$ & - & - & - & $18.0 \pm 0.00$ & - \\
\hline & $\mathrm{ACP} 4 \mathrm{~A}$ & - & - & - & $18.0 \pm 0.00$ & - \\
\hline
\end{tabular}

\begin{tabular}{ll}
\hline Note: & \\
- & No inhibition zone \\
Positive control : & Amphotericin $20 \mu \mathrm{mL}^{-1}$ \\
Negative control: & Distilled water
\end{tabular}

\section{DETERMINATION OF MIC AND MBC/MFC}

Tables 4 and 5 showed the result of the broth microdilution method of the compounds against nine microorganisms tested. As seen in Table 4, only $S$. aureus was susceptible to ACP 4A out of a total of five bacterial species screened. The MIC value of ACP 4A was $800 \mu \mathrm{g} \mathrm{mL}^{-1}$ compared to the MIC value of Gentamicin at a range of 0.125 to $8 \mu \mathrm{g} \mathrm{mL}^{-1}$ against $S$. aureus. ACP 4A, however, exhibited antifungal 
activity against all the four fungal species tested, namely, C. albicans, C. glabrata, A. niger, and A. fumigatus (Table 5). The lowest MIC values obtained for the ACP $4 \mathrm{~A}$ was against $A$. niger and $A$. fumigatus, which was $200 \mu \mathrm{g}$ $\mathrm{mL}^{-1}$. This value showed that $A$. niger and $A$. fumigatus were more susceptible to ACP 4A compared to both the Candidal strains. Similar to $S$. aureus, both C. glabrata and $C$. albicans also showed the same MIC value of 800 $\mu \mathrm{g} \mathrm{mL}^{-1}$ by ACP4A. However, the MBC/MFC value of ACP
4A against $S$. aureus and C. albicans was higher than 800 $\mu \mathrm{g} \mathrm{mL}{ }^{-1}$, whereas the MFC value of ACP 4A against $C$. glabrata was $800 \mu \mathrm{g} \mathrm{mL}^{-1}$. In other words, the MIC and MBC values of the ACP 4A against $C$. glabrata were the same, which was $800 \mu \mathrm{g} \mathrm{mL} \mathrm{m}^{-1}$. The MFC values of ACP 4A against $A$. niger and $A$. fumigatus appeared to be higher than $800 \mu \mathrm{g} \mathrm{mL}^{-1}$ and cannot be determined as the test concentration was from 25 to $800 \mu \mathrm{g} \mathrm{mL}^{-1}$.

TABLE 4. MIC and MBC values for six heterocyclic organic compounds against tested bacteria

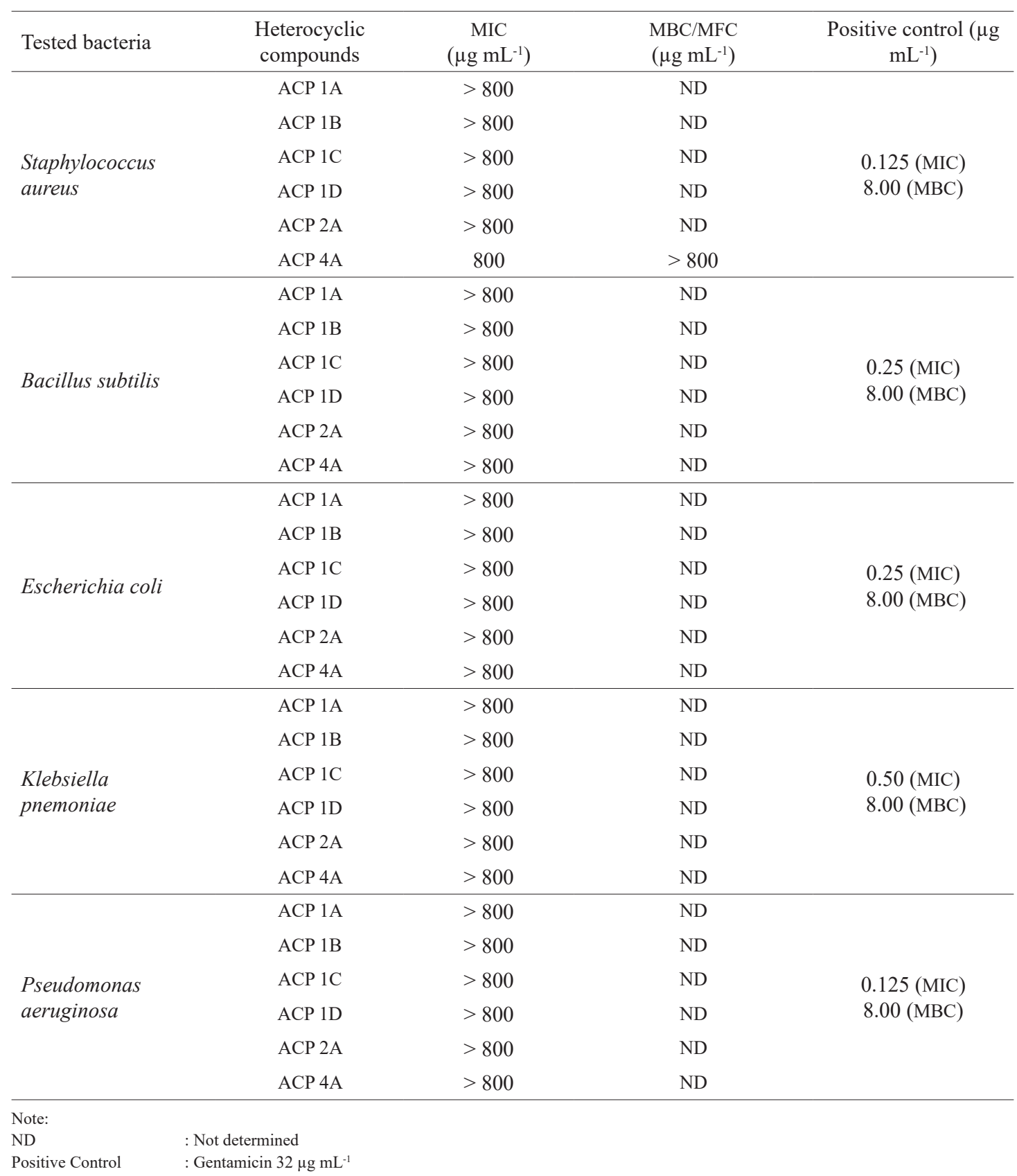


TABLE 5. MIC and MBC values for six heterocyclic organic compounds against tested fungi

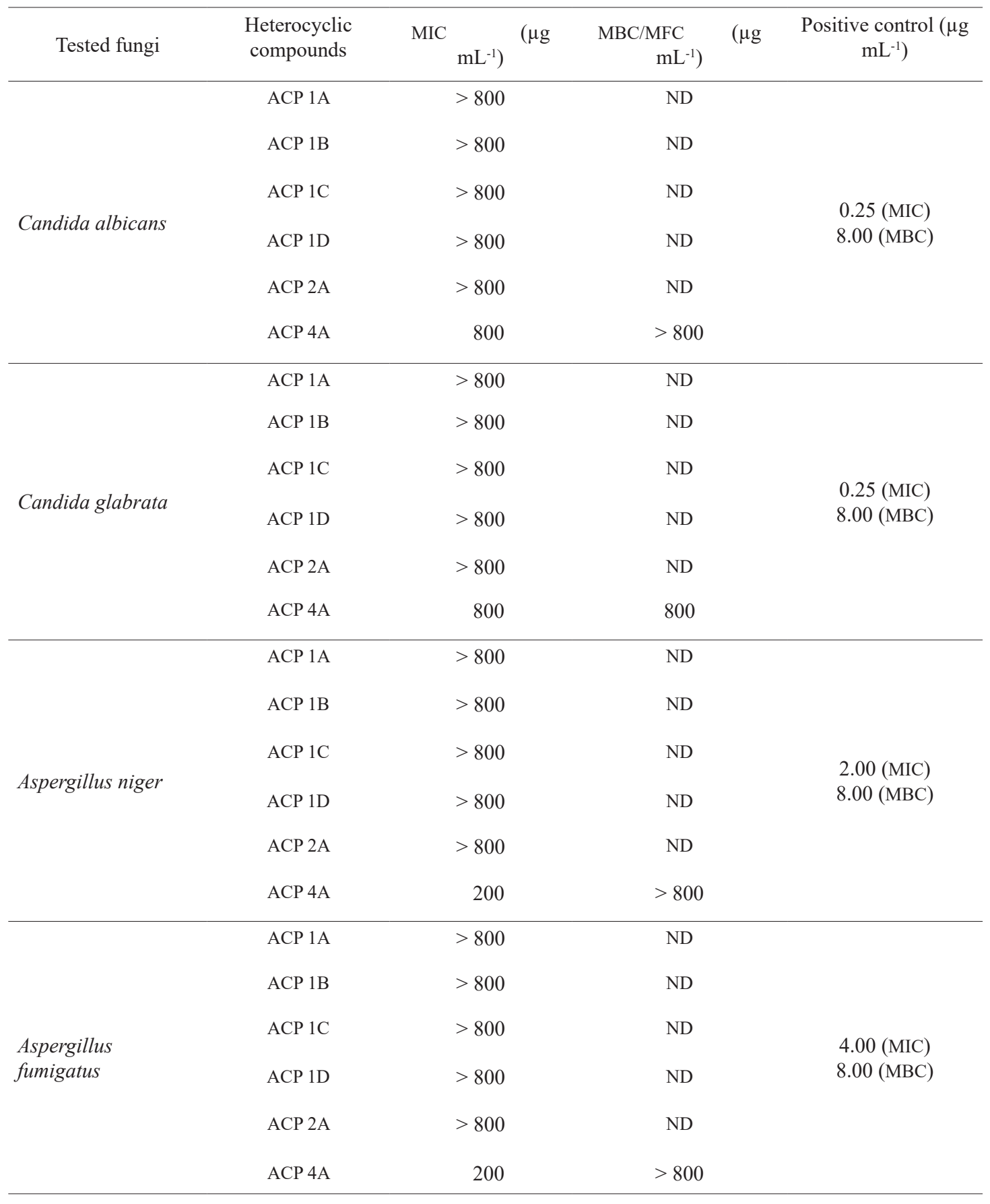

Note:

ND: Not determined

Positive Control: Amphotericin B $32 \mu \mathrm{g} \mathrm{mL}^{-1}$

DETERMINATION OF TKA ANALYSIS

As seen from Figure 1, the ACP 4A compound at $1 \times$ MIC and $2 \times$ MIC concentration did not show the fungicidal effect against $A$. fumigatus throughout the $24 \mathrm{~h}$ incubation period. The plot of time-kill assay illustrated no reduction of colony count of more than $3 \log _{10} \mathrm{CFU} \mathrm{mL} \mathrm{m}^{-1}$ by ACP $4 \mathrm{~A}$ and regrowth of the $A$. fumigatus occurred at the $8^{\text {th }}$ hours at both concentrations. 


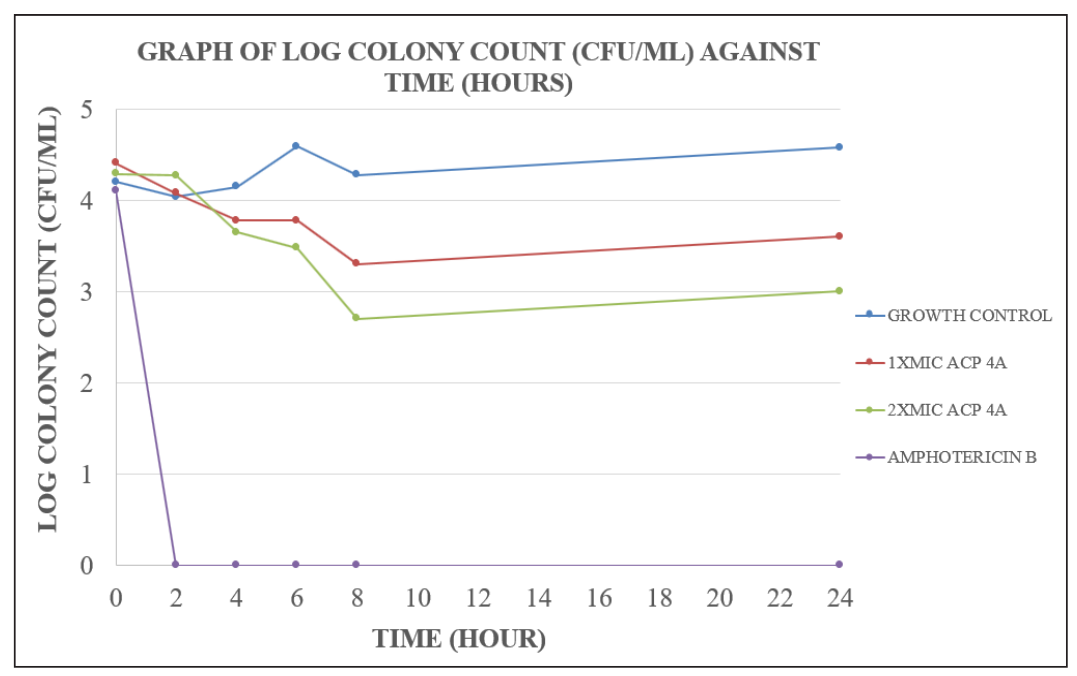

FIGURE 1. Graph of $\log \left(\mathrm{CFU} \mathrm{mL} \mathrm{mL}^{-1}\right)$ against time (hours). Graph showing the time-kill curve for $A$. fumigatus which treated with $\mathrm{ACP} 4 \mathrm{~A}$ compound, amphotericin B and growth control

\section{DISCUSSION}

Life-threatening pathogenic microorganisms infection is on the rise and becoming the leading cause of death worldwide (Stein 2011). Toxic effects from the current use of antimicrobial agents have limited the selection of drugs in treating the diseases (Mandhane et al. 2015). Therefore, novel heterocyclic organic compounds such as ACP 1A, ACP 1B, ACP 1C, ACP 1D, ACP 2A, and ACP $4 \mathrm{~A}$ were assessed for their antimicrobial activity against five bacteria and four fungi species.

From the agar well diffusion assay, only ACP 4A showed antimicrobial activity, and the rest of the novel heterocyclic organic compounds was not capable of inhibiting the growth of all nine tested microorganisms. Among all the tested bacteria and fungi, only Escherichia coli was susceptible to ACP 4A despite being 2000-3000 times less potent than gentamicin as an antimicrobial agent against $E$. coli. For pure compound, this cannot be considered an important finding as the potency of ACP $4 \mathrm{~A}$ would ideally be better or close to the positive control.

The identification and characterization of the effect of compounds against the tested microorganisms by comparing the MIC and MBC values of each compound are also crucial. From the broth microdilution assay, it was shown that MBC values of ACP 4A against $S$. aureus, $C$. albicans, A. niger, and A. fumigatus were higher than their MIC values. As such, it can be interpreted that ACP 4A displayed bacteriostatic against $S$. aureus and fungistatic against $C$. albicans, $A$. niger, and $A$. fumigatus. However, out of these four susceptible tested microorganisms, ACP 4A was equally potent against both $A$. niger and $A$. fumigatus with the lowest MIC values among all the susceptible tested microorganisms. This observation indicated that as a fungistatic agent, ACP $4 \mathrm{~A}$ was more effective in combating the filamentous fungi compared to yeast and bacteria studied. While for C. glabrata, the MIC and MBC values were the same and can be interpreted that the ACP 4A exhibited a fungicidal effect against $C$. glabrata. The presence of the electron-withdrawing group $(\mathrm{Cl})$ at the para position of the quinoline ring and halogen atom, which is the bromine in the chemical structure, could be responsible for the antimicrobial activity. Aforementioned, it is in line with the results obtained by Garudachari et al. (2012) and Shakhatreh et al. (2016), which had shown that the presence of an electron-withdrawing group could increase the antimicrobial activity. The other five heterocyclic compounds did not show any inhibition activity against tested microorganisms, which is due to the absence of halogen atom in their chemical structures. According to the study of Bahrin et al. (2016), halogen atoms could influence antimicrobial activity.

However, the study showed a contradictory result between agar well diffusion assay and micro broth dilution assay. The concentration of compounds applied in agar well diffusion assay was higher than in MIC assay. Nonetheless, it was still incapable of inhibiting the growth of five susceptible microorganisms, as shown in the MIC assay. Herein, no linear relationship between the size of the inhibition zone and the concentration of tested compounds was observed. Moreover, the methods employed in these two assays were different. In agar well diffusion assay, the solid medium was applied, whereas, in the MIC assay, the liquid medium is preferable. Hence, the results obtained were different. 
Noteworthy, using the wrong solvent to dilute the compound could be the factor that caused the incomplete dissolving of the compound. In this study, ACP 4A was diluted in the wrong solvent. ACP 4A should be diluted in methanol instead of DMSO since it is a polar solvent, and thus ACP 4A was cannot completely dissolve in DMSO. Methanol is an organic solvent that possesses amphiphilic property (Mallamace et al. 2016), where it can dilute both polar and non-polar solute. Therefore, methanol should be used to dissolve ACP 4A with the addition of heat between 25 and $30{ }^{\circ} \mathrm{C}$ for it to dissolve completely.

According to King et al. (2008), Klančnik et al. (2010) and Mann and Markham (1998), non-polar compound prevented the uniform diffusion through the agar media. Moreno et al. (2006) stated that the absence of inhibition zone did not mean that the compound was not inhibitory against the growth of microorganisms, especially the nonpolar compound, which would diffuse more slowly into the agar media. Other than that, the ACP 4A compound has the molecular weight slightly higher than the natural compound as it involves two benzene rings and bromine in the chemical structure. Osés et al. (2016) also reported that high molecular weight could limit the diffusion in agar media. With the factors mentioned, it is hard for the partially dissolved and non-polar compound to be in contact with microorganisms seeded on the surface of the agar medium as compared to using a liquid medium that is in direct contact with the microorganisms. Hence, the results obtained from the agar well diffusion assay did not align with the results produced by MIC assay.

The time-kill assay was conducted on the susceptible microorganism to confirm the results obtained from MIC and MBC assays. A. fumigatus was selected as it is more pathogenic than $A$. niger. The fungicidal effect was not detected at $1 \times \mathrm{MIC}$ and $2 \times \mathrm{MIC}$ of $\mathrm{ACP} 4 \mathrm{~A}$ as there was no reduction of colony count for about $3 \log _{10} \mathrm{CFU} \mathrm{mL} \mathrm{mL}^{-1}$. On the contrary, the number of colonies increased from 8 to $24 \mathrm{~h}$ throughout the incubation period indicating a higher concentration of the compound is needed to produce the fungicidal effect.

Through the findings of this study, the micro broth dilution technique produced a more specific and reliable result than the agar well diffusion method, and the TKA assay confirmed the fungistatic activity of ACP 4A has against Aspergillus fumigatus.

\section{CONCLUSION}

ACP 4A compound was the only compound among the six heterocyclic organic compounds that were capable of inhibiting the growth of $E$. coli in agar well diffusion assay. However, assessment of MIC and MBC determination through the broth microdilution method and streak plate technique showed that ACP $4 \mathrm{~A}$ was capable of inhibiting the growth of E. coli. However, it showed the bacteriostatic effect against $S$. aureus, fungicidal against $C$. glabrata, but was fungistatic against $C$. albicans, A. niger, and $A$. fumigatus. TKA assay confirmed the MIC and MFC results that ACP 4A was fungistatic against A. fumigatus. Hence, the ACP 4A compound has the potential to be developed as an alternative treatment for $A$. fumigatus infection.

\section{ACKNOWLEDGEMENTS}

This project is funded under the Ministry of Higher Education, Malaysia (Grant code: FRGS/1/2019/STG01/ $\mathrm{UKM} / 02 / 3$ ).

\section{REFERENCES}

Ambethkar, S., Padmini, V. \& Bhuvanesh, N. 2015. A green and efficient protocol for the synthesis of dihydropyranol[2,3-c] pyrazole derivatives via a one-pot, four component reaction by grinding method. Journal of Advanced Research 6(6): 975-985.

Bahrin, L.G., Sarbu, L.G., Hopf, H., Jones, P.G., Babii, C., Stefan, M. \& Birsa, M.L. 2016. The influence of halogen substituents on the biological properties of sulfur-containing flavonoids. Bioorganic \& Medicinal Chemistry 24(14): 3166-3173.

CLSI. 2008. M38-A2. Reference Method for Broth Dilution Antifungal Susceptibility Testing of Filamentous Fungi; approved standard-second edition. CLSI, Wayne, PA, USA.

Constantino, L. \& Barlocco, D. 2006. Privileged structures as leads in medicinal chemistry. Current Medicinal Chemistry 13(1): 65-85.

El Shehry, M.F., Ghorab, M.M., Abbas, S.Y., Fayed, E.A., Shedid, S.A. \& Ammar, Y.A. 2018. Quinoline derivatives bearing pyrazole moiety: Synthesis and biological evaluation as possible antibacterial and antifungal agents. European Journal of Medicinal Chemistry 143(2018): 1463-1473.

Eswaran, S., Adhikari, A.V., Chowdhury, I.H., Pal, N.K. \& Thomas, K. 2010. New quinoline derivatives: synthesis and investigation of antibacterial and antituberculosis properties. European Journal of Medicinal Chemistry 45(8): 3374-3383.

Garudachari, B., Satyanarayana, M., Thippeswamy, B., Shivakumar, C., Shivananda, K., Hegde, G. \& Isloor, A.M. 2012. Synthesis, characterization and antimicrobial studies of some new quinoline incorporated benzimidazole derivatives. European Journal of Medicinal Chemistry 54(2012): 900906.

Joly, V., Bolard, J. \& Yeni, P. 1992. In vitro models for studying toxicity of antifungal agents. Antimicrobial Agents and Chemotherapy 36(9): 1799-1804.

Kamath, P.R., Sunil, D. \& Ajees, A.A. 2016. Synthesis of indole-quinoline-oxadiazoles: Their anticancer potential and computational tubulin binding studies. Research on Chemical Intermediates 42(6): 5899-5914.

Kaur, K., Jain, M., Reddy, R.P. \& Jain, R. 2010. Quinolines and structurally related heterocycles as antimalarials. European Journal of Medicinal Chemistry 45(8): 3245-3264.

King, T., Dykes, G. \& Kristianti, R. 2008. Comparative evaluation of methods commonly used to determine antimicrobial susceptibility to plant extracts and phenolic compounds. Journal of AOAC International 91(6): 1423-1429.

Klančnik, A., Piskernik, S., Jeršek, B. \& Možina, S.S. 2010. Evaluation of diffusion and dilution methods to determine 
the antibacterial activity of plant extracts. Journal of Microbiological Methods 81(2): 121-126.

Mallamace, F., Corsaro, C., Mallamace, D., Vasi, C., Vasi, S. \& Stanley, H.E. 2016. Dynamical properties of water-methanol solutions. The Journal of Chemical Physics 144(6): 064506.

Mandhane, P.G., Joshi, R.S., Mahajan, P.S., Nikam, M.D., Nagargoje, D.R. \& Gill, C.H. 2015. Synthesis, characterization, and antimicrobial screening of substituted quiazolinones derivatives. Arabian Journal of Chemistry 8(4): 474-479.

Mann, C. \& Markham, J. 1998. A new method for determining the minimum inhibitory concentration of essential oils. Journal of Applied Microbiology 84(4): 538-544.

Mohammat, M.F., Maarop, M.S., Shaameri, Z., Wibowo, A., Johari, S.A. \& Hamzah, A.S. 2018. Practical synthesis and electronic study of non-spiro and spiropyrano [2, 3-c] pyrazole-3-carboxylate derivatives via uncatalyzed domino one-pot, four-component reactions. Organic Communication 11: 149-162.

Moreno, S., Scheyer, T., Romano, C.S. \& Vojnov, A.A. 2006. Antioxidant and antimicrobial activities of rosemary extracts linked to their polyphenol composition. Free Radical Research 40(2): 223-231.

Musiol, R., Serda, M., Hensel-Bielowka, S. \& Polanski, J. 2010a. Quinoline-based antifungals. Current Medicinal Chemistry 17(18): 1960-1973.

Musiol, R., Jampilek, J., Nycz, J.E., Pesko, M., Carroll, J., Kralova, K., Vejsova, M., O’Mahony, J., Coffey, A., Mrozek, A. \& Polanski, J. 2010b. Investigating the activity spectrum for ring-substituted 8-hydroxyquinolines. Molecules 15(1): 288-304.

Osés, S.M., Pascual-Mate, A., De La Fuente, D., De Pablo, A., Fernandez-Muino, M.A. \& Sancho, M.T. 2016. Comparison of methods to determine the antibacterial activity of honeys against Staphylococcus aureus. NJAS-Wageningen Journal of Life Sciences 78(2016): 29-33.

Pawar, P., Mane, B., Salve, M. \& Bafana, S. 2017. Synthesis and anticonvulsant activity of n-substituted-7-hydroxy-4-methyl2-oxa-quinoline derivatives. International Journal of Drug Research and Technology 3(3): 60-66.

Ramírez-Prada, J., Robledo, S.M., Vélez, I.D., del Pilar Crespo, M., Quirogo, J., Abonia, R., Montoya, A., Svetaz, L., Zacchino, S. \& Insuasty, B. 2017. Synthesis of novel quinoline-based 4,5-dihydro- $1 H$-pyrazoles as potential anticancer, antifungal, antibaterial and antiprotozoal agents. European Journal of Chemistry 131(2017): 237-254.

Shakhatreh, M.A.K., Al-Smadi, M.L., Khabour, O.F., Shuaibu, F.A., Hussein, E.I. \& Alzoubi, K.H. 2016. Study of the antibacterial and antifungal activities of synthetic benzyl bromides, ketones, and corresponding chalcone derivatives. Drug Design, Development and Therapy 10(2016): 3653.

Stein, R.A. 2011. Bacterial infections of humans: Epidemiology and control. JAMA 305(14): 1488-1489.

Vaghasiya, R., Ghodasara, H., Vachharajani, P. \& Shah, V. 2014. Synthesis, characterization, and biological evaluation of 6-substituted-2-(substituted-phenyl)-quinoline derivatives bearing 4-amino-1, 2, 4-triazole-3-thiol ring at c-4 position. International Letters of Chemistry, Physics and Astronomy 8: 30-37.

Vandekerckhove, S., Tran, H.G., Desmet, T. \& D'hooghe, M. 2013. Evaluation of (4-aminobutyloxy) quinolines as a novel class of antifungal agents. Bioorganic \& Medicinal Chemistry Letters 23(16): 4641-4643.

Dayang Fredalina Basri \& Kuek Sze Yee

Centre for Diagnostic, Therapeutic \& Investigative Studies (CODTIS)

Faculty of Health Sciences

Universiti Kebangsaan Malaysia

Jalan Raja Muda Abdul Aziz

50300 Kuala Lumpur, Federal Territory

Malaysia

Jacinta Santhanam

Centre for Toxicology and Health Risk Studies (CORE)

Faculty of Health Sciences

Universiti Kebangsaan Malaysia

Jalan Raja Muda Abdul Aziz

50300 Kuala Lumpur, Federal Territory

Malaysia

Mohd Asyraf Shamsudin, Nur Hanis Zakaria, Jalifah Latip \& Nurul Izzaty Hassan*

Department of Chemical Sciences

Faculty of Science and Technology

Universiti Kebangsaan Malaysia

43600 UKM Bangi, Selangor Darul Ehsan

Malaysia

*Corresponding author; email: drizz@ukm.edu.my

Received: 27 August 2019

Accepted: 4 May 2020 